\title{
THE FATE OF INGESTED PSEUDOMONAS AERUGINOSA IN NORMAL PERSONS
}

\author{
A. C. Buck And E. Mary CoOKe \\ Department of Bacteriology, St Bartholomew's Hospital, London
}

A NUMBER of sources of Pseudomonas aeruginosa have been suggested that may be of importance in ward infection. These are contaminated solutions of disinfectants (Lowbury, 1951; Plotkin and Austrian, 1958; Lee and Fialkow, 1961), aspirators, respirators and incubators (Barrie, 1965; Bassett, Thompson and Page, 1965; Phillips and Spencer, 1965; Rubbo, Gardner and Franklin, 1966) and severely infected patients, especially burned patients (Lowbury and Fox, 1954; Sutter and Hurst, 1966) and patients with urinary infections (Pyrah et al., 1955; Gillespie et al., 1964). In general medical and surgical wards another source of importance may be the gastro-intestinal tract of the patients (Darrell and Wahba, 1964; Shooter et al., 1966).

It is possible that pseudomonas in the bowel come from ingested food, but it is not known whether ingested pseudomonas will establish themselves in the bowel of normal people, what numbers if ingested will be detectable in the faeces and for how long they will remain in the bowel. The experiments described here were performed in an attempt to answer these questions.

\section{METHODS}

Volunteers. These were two men and one woman who were members of the laboratory staff. Their ages were between 29 and 35 and they had no known abnormality of the gastrointestinal tract. During the period of the investigation the volunteers ate no cold food at midday and all cold food and drinks taken at home were sampled for the presence of pseudomonas. On three occasions one of the volunteers had a 4-day course of oral ampicillin, $250 \mathrm{mg}$ being taken 4 times a day, commencing $5 \mathrm{hr}$ before the ingestion of the organisms.

Strains. The doses of pseudomonas to be ingested were prepared from either laboratory strains or fresh isolates. The sources, the phage-types and serotypes of the seven strains used are shown in table I.

Preparation of strains of pseudomonas for ingestion. The strains were grown in nutrient broth (Oxoid) at $37^{\circ} \mathrm{C}$ for $5 \mathrm{hr}$ and then either this culture or dilutions of it were added to approximately $200 \mathrm{ml}$ of milk containing $4 \mathrm{ml}$ of aluminium hydroxide gel. The numbers of organisms ingested ranged from $5 \times 10^{2}$ to $2 \times 10^{8}$, determined from surface viable counts of the broth cultures on cetrimide-chloramphenicol plates. The organisms were ingested in the late afternoon approximately $4 \mathrm{hr}$ after the last meal.

Composition of the media used. Cetrimide broth: Oxoid nutrient broth no. 2 containing $0.2 \mathrm{mg}$ cetrimide per $\mathrm{ml}$. Cetrimide agar: Oxoid nutrient agar containing $0.3 \mathrm{mg}$ cetrimide per $\mathrm{ml}$. Cetrimide-chloramphenicol agar: as for cetrimide agar but with the addition of $2 \cdot 5 \mu \mathrm{g}$ chloramphenicol per $\mathrm{ml}$.

Examination of food. A few grammes of each type of cold food or cold drink eaten during a 24-hr period were pooled and emulsified. The mixture was used to inoculate a cetrimide agar plate and also a tube of cetrimide broth, which was subcultured to cetrimide agar after

Received 12 Apr. 1969; accepted 2 May 1969.

J. MED, MICROBIOL.-VOL. 2 (1969) 
overnight incubation. Preliminary experiments had shown that by these methods 10 pseudomonas per $\mathrm{ml}$ of food suspension could be detected.

Examination of faeces. Specimens of faeces were examined as soon as they were passed, except on a few occasions when they were stored at $4^{\circ} \mathrm{C}$ for periods not exceeding $24 \mathrm{hr}$ before they were examined. Three samples each of approximately $2 \mathrm{~g}$ were taken from different parts of the stool and emulsified in water to form a thin paste. This paste and ten-fold dilutions in quarter-strength Ringer's solution were used to inoculate cetrimide-chloramphenicol plates for surface viable counts. By these methods the lower limit of detection of pseudomonas in the faeces was 10 organisms per $\mathrm{g}$. A single colony of pseudomonas from each specimen was stored for phage- and sero-typing.

TABLE I

Pseudomonas strains

\begin{tabular}{c|l|l|c}
\hline Strain & \multicolumn{1}{|c|}{ Origin } & \multicolumn{1}{|c|}{ Phage-type } & Serotype \\
& & & \\
\cline { 3 - 3 } 1 & Environment* & $21 / 68 / 119 \mathrm{X} / 1214 / \mathrm{Col} 21$ & 10 \\
2 & Faeces* & $7 / 31 / \mathrm{M} 4 / \mathrm{Col} 11$ & 10 \\
3 & Jelly* & $7 / 31 / 73 / 109 / \mathrm{M} 4$ & 6 \\
4 & Faeces* & $7 / 21 / 68 /+$ & 1 \\
5 & Faeces $\dagger$ & $24 / 68 / \mathrm{F} 7 / \mathrm{Col} \mathrm{11}$ & Not typable \\
6 & Tracheal swab $\dagger$ & $7 / 21 / 24 / 68 / \mathrm{Col} 11$ & 3 \\
7 & Faeces $\dagger$ & $21 / 1214 / \mathrm{Col} \mathrm{18}$ & 11 \\
\hline
\end{tabular}

* Laboratory stock strain. $\quad \uparrow$ Fresh isolate.

\section{RESULTS \\ Examination of food}

The cold food consumed was examined continuously in one household for $13 \mathrm{wk}$ and in another for $4 \mathrm{wk}$. On no occasion was pseudomonas isolated.

\section{Examination of faeces}

The results of the ingestion of pseudomonas by the three volunteers are shown in table II. Doses of less than $10^{4}$ organisms were not detectable in the faeces, but regular recovery was obtained with doses above $10^{6}$ organisms.

The highest counts were usually obtained in the first specimen passed, provided that at least $12 \mathrm{hr}$ had elapsed since ingestion of the organisms. Counts then fell steadily in subsequent specimens and after 6 days organisms were no longer detectable, except on one occasion when ampicillin was also taken and colonisation occurred. In this case excretion persisted steadily for 14 days before it ceased spontaneously. Subsequent administration of this pseudomonas and also of a different serotype together with ampicillin failed to establish colonisation in the same volunteer. The total number of organisms recovered from the stools was only a small percentage of the ingested dose, except on the occasion colonisation occurred, when the total number recovered exceeded the ingested dose.

Stool strains were always identical in serotype and phage-type with the strain ingested immediately before their recovery. 
None of the volunteers experienced any untoward reactions as a result of taking pseudomonas and when colonisation occurred it was not accompanied by any gastro-intestinal tract upset.

TABLE II

Oral administration of pseudomonas and recovery in the faeces

\begin{tabular}{|c|c|c|c|c|c|}
\hline Subject & $\begin{array}{c}\text { Strain of } \\
\text { pseudomonas }\end{array}$ & $\begin{array}{c}\text { Oral dose } \\
\text { of } \\
\text { pseudomonas }\end{array}$ & $\begin{array}{c}\text { Time (hr) } \\
\text { between } \\
\text { administration } \\
\text { of pseudomonas } \\
\text { and first } \\
\text { appearance in } \\
\text { the faeces }\end{array}$ & $\begin{array}{l}\text { Time in days } \\
\text { between first } \\
\text { and last } \\
\text { positive specimen } \\
\text { of faeces }\end{array}$ & $\begin{array}{l}\text { Total number } \\
\text { of } \\
\text { pseudomonas } \\
\text { recovered } \\
\text { from the } \\
\text { faeces }\end{array}$ \\
\hline $\begin{array}{l}\text { A } \\
\text { B } \\
\text { A } \\
\text { B } \\
\text { A } \\
\text { B } \\
\text { A }\end{array}$ & $\begin{array}{l}1 \\
1 \\
1 \\
1 \\
1 \\
1 \\
1\end{array}$ & $\begin{array}{l}5.0 \times 10^{2} \\
5.0 \times 10^{2} \\
7 \cdot 5 \times 10^{3} \\
7 \cdot 5 \times 10^{3} \\
7 \cdot 5 \times 10^{7} \\
7 \cdot 5 \times 10^{7} \\
1 \cdot 5 \times 10^{6}\end{array}$ & $\begin{array}{l}\bar{z} \\
\bar{z} \\
24 \\
72 \\
18\end{array}$ & $\begin{array}{l}0 \\
0 \\
0 \\
0 \\
3 \\
2 \\
3\end{array}$ & $\begin{array}{c}0 \\
0 \\
0 \\
0 \\
\overline{-} \\
3.0 \times 10^{4}\end{array}$ \\
\hline $\begin{array}{l}\mathbf{A} \\
\mathrm{A}^{*} \\
\mathrm{~A}^{*} \\
\mathrm{~A}^{*} \\
\mathbf{A} \\
\mathbf{C}\end{array}$ & $\begin{array}{l}2 \\
2 \\
2 \\
2 \\
2 \\
2\end{array}$ & $\begin{array}{l}1.0 \times 10^{7} \\
3.0 \times 10^{6} \\
2.0 \times 10^{8} \\
1 \cdot 5 \times 10^{8} \\
3.0 \times 10^{6} \\
3 \cdot 0 \times 10^{6}\end{array}$ & $\begin{array}{l}18 \\
24 \\
18 \\
24 \\
24 \\
24\end{array}$ & $\begin{array}{r}3 \\
14 \\
2 \\
6 \\
2 \\
2\end{array}$ & $\begin{array}{c}2.5 \times 10^{5} \\
>4.0 \times 10^{6 \dagger} \\
7.5 \times 10^{5} \\
3.5 \times 10^{5} \\
1.0 \times 10^{4} \\
3.5 \times 10^{3}\end{array}$ \\
\hline $\begin{array}{l}\mathbf{A} \\
\mathbf{A}^{*}\end{array}$ & $\begin{array}{l}3 \\
3 \\
3\end{array}$ & $\begin{array}{l}7.0 \times 10^{7} \\
1.0 \times 10^{7} \\
7.0 \times 10^{7}\end{array}$ & $\begin{array}{l}24 \\
18 \\
18\end{array}$ & $\begin{array}{l}4 \\
2 \\
5\end{array}$ & $\begin{array}{l}1 \cdot 5 \times 10^{7} \\
2 \cdot 0 \times 10^{5} \\
2 \cdot 0 \times 10^{6}\end{array}$ \\
\hline $\begin{array}{l}\mathrm{A} \\
\mathbf{C} \\
\mathrm{A} \\
\mathrm{C}\end{array}$ & $\begin{array}{l}4 \\
4 \\
4 \\
4\end{array}$ & $\begin{array}{l}5 \cdot 0 \times 10^{7} \\
5 \cdot 0 \times 10^{7} \\
2 \cdot 0 \times 10^{8} \\
2 \cdot 0 \times 10^{8}\end{array}$ & $\begin{array}{l}18 \\
30 \\
24 \\
-\end{array}$ & $\begin{array}{l}6 \\
1 \\
2 \\
0\end{array}$ & $\begin{array}{c}2 \cdot 0 \times 10^{6} \\
2 \cdot 0 \times 10^{3} \\
1 \cdot 0 \times 10^{4} \\
0\end{array}$ \\
\hline $\begin{array}{l}\mathbf{A} \\
\mathbf{A} \\
\mathbf{A}\end{array}$ & $\begin{array}{l}5 \\
6 \\
7\end{array}$ & $\begin{array}{l}1.0 \times 10^{8} \\
1.5 \times 10^{8} \\
1.0 \times 10^{8}\end{array}$ & $\begin{array}{l}24 \\
18 \\
42\end{array}$ & $\begin{array}{l}2 \\
2 \\
2\end{array}$ & $\begin{array}{l}4.0 \times 10^{4} \\
6 \cdot 5 \times 10^{5} \\
2 \cdot 5 \times 10^{6}\end{array}$ \\
\hline
\end{tabular}

* Oral ampicillin administered.

$\dagger$ Colonisation achieved. Not all specimens were counted although they all contained pseudomonas.

\section{Discussion}

The results show that if $10^{6}$ or more pseudomonas are ingested the organism can be recovered from the faeces. This dose did not lead to colonisation; the organisms passed through the bowel and excretion soon ceased.

Although the domestically prepared food studied did not contain pseudomonas, work in progress in our laboratory has shown that institutionally prepared food may do so. It is possible that this source may account in part for the faecal carriage rate observed in this hospital (Shooter et al., 1966).

The interesting points observed in these experiments about the passage of pseudomonas through the bowel were the speed at which the organisms passed 
through and the fact that excretion was transient. In any studies in which the relation of faecal carriage to food contamination is being examined the timing of the examination of specimens will be important.

Other organisms that have been experimentally or therapeutically ingested by normal people and by patients with disease of the bowel are Escherichia coli and lactobacilli. It has been shown that large numbers of $E$. coli administered to patients with ulcerative colitis will displace the strain previously present in the bowel (Cooke, 1966). E. coli $\mathrm{O} 111$ has been administered to adults and has caused diarrhoea (Ferguson and June, 1952) and a non-enteropathogenic strain of $E$. coli has been established in the bowel of infants (Lodinová, Jouja and Lanc, 1967). For many years lactobacilli have been administered to patients for the treatment of a variety of conditions (Portis and Albus, 1931; Winkelstein, 1956; and Settel, 1962). In particular they have been administered with broad-spectrum antibiotics to prevent colonisation of the bowel with staphylococci (Gordon, Macrae and Wheater, 1957; Török and Turay, 1960).

In all this work large numbers of organisms have been administered, and in the work reported here $10^{6}$ organisms were administered before they were regularly detected in the faeces. However, though the proportion of the ingested dose present in the faeces was usually small, it did vary considerably, so that among a larger group of people there would be probably some in whom on occasion smaller doses could be detected. Frequent small oral doses might also be more readily detectable.

The results indicate one factor that may be of importance in establishing colonisation-the administration of antibiotics. Ampicillin was used in the study, but an antibiotic such as tetracycline with a wider spectrum of activity against the normal bowel flora might have been more effective. However, it is known that colonisation may occur in the absence of antibiotics. Whether the establishment of colonisation is due to a particular property of the strain of organisms or to some unidentified characteristic of the carrier is not known.

\section{SUMMARY}

Cultures of Pseudomonas aeruginosa in milk were ingested by three normal people. The organisms were recovered from the faeces if $10^{6}$ or more were ingested. They were present in the greatest number in the first specimen passed, provided this was $12 \mathrm{hr}$ or more after administration of the organisms. The numbers excreted were less than those ingested and excretion did not continue longer than 6 days. Colonisation was achieved on one occasion when ampicillin was also administered.

We are grateful to Dr M. T. Parker who typed the strains of pseudomonas and to Professor R. A. Shooter for his advice.

\section{REFERENCES}

Barrie, DinaH . . . . . . . . 1965. Archs Dis. Childh., 40, 555.

Bassett, D. C. J., Thompson, Sheila 1965. Lancet, 1, 781.

A. S., AND Page, Beryl 
COOKe, E. MARY ． . . . . . . 1966. M.D. Thesis, Univ. London.

Darrell, J. H., and Wahba, A. H. . . 1964. J. Clin. Path., 17, 236.

Ferguson, W. W., and June, R. C. . . 1952. Amer. J. Hyg., 55, 155.

Gillespie, W. A., LenNon, G. G., 1964. Br. Med. J., 2, 423.

LINTON, K. B., AND SLADE, N.

Gordon, D., Macrae, J., AND Wheater, 1957. Lancet, 1, 899.

DOROTHY M.

LeE, J. C., and Fialkow, P. J. . . . 1961. J. Amer. Med. Assoc., 177, 708.

LODINOVÁ, R., JoUjA, V., AND LANC, A. 1967. Z. ImmunForsch. exp. Ther., 133, 22.

Lowbury, E. J. L. . . . . . . . 1951. Br. J. Ind. Med., 8, 22.

Lowbury, E. J. L., AND Fox, JeAN . . 1954. J. Hyg., Camb., 52, 403.

Phillips, I., AND SPencer, G. . . . 1965. Lancet, 2, 1325.

Plotkin, S. A., ANd Austrian, R. . . . 1958. Amer. J. Med. Sci., 235, 621.

Portis, M. M., and Albus, W. R. . . 1931. Amer. J. Surg., 12, 85.

Pyrah, L. N., Goldie, W., Parsons, 1955. Lancet, 2, 314. F. M., AND RAPER, F. P.

Rubbo, S. D., Gardner, Joan F., AND 1966. J. Hyg., Camb., 64, 121. Franklin, J. Clare

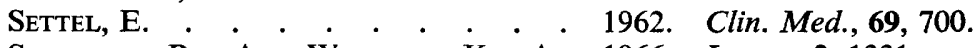

SHOOTER, R. A., WALKeR, K. A., 1966. Lancet, 2, 1331. Williams, Veronica R., Horgan, Gillian M., PARKer, M. T., Asheshov, Elizabeth H., AND BUlliMORE, JULIET F.

Sutter, Vera L., and Hurst, Valerie

TöröK, J., AND TURAY, P. • • • . 1960. 'Kinderärztl. Prax., 28, 385.

1966. Ann. Surg., 163, 597.

Winkelstein, A. - . . . - . - 1956. Amer. Practnr Dig. Treat., 7, 1637. 